\title{
Pemanfaatan Teknologi Informasi Dalam Mendukung Posyandu Terkait Dengan Tumbuh Kembang Anak
}

\author{
Liliana \\ Program Studi Sistem Informasi \\ Universitas Surabaya \\ lili@staff.ubaya.ac.id
}

\author{
Dhiani Tresna Absari \\ Program Studi Sistem Informasi \\ Universitas Surabaya \\ dhiani@staff.ubaya.ac.id
}

\begin{abstract}
Abstrak - Tumbuh kembang anak di usia masa emas, yaitu 0 hingga 5 tahun, memiliki pengaruh yang cukup besar dalam pertumbuhannya di masa mendatang. Untuk itu, orang tua wajib memantau perkembangan anaknya dengan teliti, salah satunya dengan memanfaatkan kegiatan Posyandu. Posyandu merupakan salah satu Upaya Kesehatan Berbasis Masyarakat (UKBM) yang dikelola dan diselenggarakan oleh masyarakat guna memberikan kemudahan kepada masyarakat dalam memperoleh pelayanan kesehatan pada ibu hamil dan balita. Melihat pertumbuhan pengguna internet yang meningkat, maka hal ini dapat digunakan sebagai salah satu alternatif solusi untuk membantu Posyandu dalam meningkatkan kesadaran orang tua, ibu secara khusus, dalam memantau tumbuh kembang anak. Saat ini, data tumbuh kembang anak sebagai dasar penilaian status gizi anak dicatat manual dalam bentuk Kartu Menuju Sehat (KMS) ataupun buku Register Kohort sehingga menimbulkan kesulitan jika catatan tersebut tidak tersedia pada saat kegiatan Posyandu berlangsung. Berdasarkan analisis yang telah dilakukan, maka dapat diambil kesimpulan bahwa untuk membantu proses yang terjadi dalam Posyandu, dibutuhkan suatu sistem terintegrasi. Aplikasi website dapat digunakan oleh semua user yang terdaftar, terutama petugas puskesmas dan Posyandu, untuk membantu entri data pada sistem. Sedangkan aplikasi mobile, dapat digunakan oleh anggota Posyandu, untuk membantu pendistribusian informasi kegiatan, pencatatan kegiatan anak, serta pengingat jadwal yang dibutuhkan.
\end{abstract}

Kata Kunci: KMS, Posyandu, Register Kohort, Tumbuh Kembang Anak..

\section{PENDAHULUAN}

Tumbuh kembang anak di usia masa emas memiliki pengaruh yang cukup besar dalam pertumbuhannya di masa mendatang. Pada usia 0 hingga 5 tahun, otak anak berkembang hingga $80 \%$ [1]. Untuk itu, orang tua wajib memantau perkembangan anaknya dengan teliti.
Berdasarkan data BPS tahun 2017, tingkat wanita bekerja adalah $50.89 \%$ angkatan kerja terhadap penduduk usia kerja (TPAK) [2]. Dengan tingkat wanita bekerja yang cukup tinggi ini, maka wanita yang telah memiliki anak sering kali harus meninggalkan anaknya dalam pengasuhan orang lain. Oleh karena itu, terdapat kemungkinan pemantauan tumbuh kembang anak dilakukan secara minimal oleh Ibu, bahkan diserahkan secara penuh pada pengasuhnya.

Posyandu merupakan salah satu Upaya Kesehatan Berbasis Masyarakat (UKBM) yang dikelola dan diselenggarakan dari, oleh, untuk dan bersama masyarakat dalam penyelanggraan pembangunan kesehatan guna memberdayakan masyarakat dan memberikan kemudahan kepada masyarakat dalam memperoleh pelayanan kesehatan dasar/sosial dasar yang memiliki kegiatan utama yang terkait dengan kesehatan ibu dan anak, keluarga berencana, imunisasi, gizi serta pencegahan dan penanggulangan diare [3]. Dalam survei yang dilakukan oleh Saepudin, Rizal, Rusman [4], menunjukkan tingkat informasi terkait kesehatan ibu dan anak yang dimiliki oleh ibu rumah tangga di usia produktif masih relatih rendah, yang sebabkan oleh kondisi kultur yang membuat para ibu berkonsentrasi mengerjakan perkerjaan rumah. Selain itu, banyak pandangan yang memarginalkan hal-hak perempuan untuk mendapatkan pendidikan yang layak, dan hal ini berujung pada rendahnya kesadaran akan pentingnya kesehatan fisik bagi seorang ibu.Berangkat dari rendahnya pengetahuan serta lingkungan yang tidak memungkinkan para ibu untuk mendapatkan informasi layanan kesehatan yang di sediakan pemerintah menjadi penyebab buruknya tumbuh kembang anak.

Berdasarkan data yang dikumpulkan oleh Kementrian Komunikasi dan Informatika Republik Indonesia [5], tingkat pengguna internet di Indonesia akan mencapai hampir 50\% pada tahun 2018. Hal ini didukung dengan membaiknya kondisi infrastruktur yang dibangun oleh Pemerintah. Bahkan menurut data yang disampaikan dalam OkeZoneFinance [6], bahwa Indonesia telah menduduki tingkat ke 4 dalam hal pengguna smartphone.

Melihat pertumbuhan pengguna internet yang meningkat, maka hal ini dapat digunakan sebagai salah satu alternatif solusi untuk membantu Posyandu dalam meningkatkan 
kesadaran orang tua, ibu secara khusus, untuk memantau tumbuh kembang anak.

\section{METODOLOGI PENELITIAN}

\section{A. Standar Antropometri Penilaian Status Gizi Anak}

Menurut Menteri Kesehatan RI [7], penilaian status gizi merupakan proses pengukuran perubahan pertumbuhan anak yang mengukur berat badan dan tinggi badan dengan melakukan perbandingan hasil pengukuran berdasarkan indeks antopometri, seperti indeks Berat Badan menurut Umur $(\mathrm{BB} / \mathrm{U})$, Berat Badan menurut Panjang Badan atau Tinggi Badan (BB/PB, BB/TB), Panjang Badan atau Tinggi Badan menurut Umur ( $\mathrm{PB} / \mathrm{U}$ atau $\mathrm{TB} / \mathrm{U}) . K a t e g o r i ~ d a n$ ambang batas status gizi dapat dilihat pada tabel 1 [7].

Tabel 1. Kategori dan Ambang Batas Status Gizi Anak Berdasarkan Indeks

\begin{tabular}{|c|c|c|}
\hline Indeks & $\begin{array}{c}\text { Kategori Status } \\
\text { Gizi }\end{array}$ & $\begin{array}{c}\text { Ambang Batas (Z } \\
\text { Score }\end{array}$ \\
\hline \multirow{4}{*}{$\begin{array}{l}\text { Berat Badan } \\
\text { menurut Umur }\end{array}$} & Gizi Buruk & $<-3 \mathrm{SD}$ \\
\hline & Gizi Kurang & $3 \mathrm{SD}$ to $<-2 \mathrm{SD}$ \\
\hline & Gizi Baik & $-2 \mathrm{SD}$ to $2 \mathrm{SD}$ \\
\hline & Gizi Lebih & $>2 \mathrm{SD}$ \\
\hline \multirow{4}{*}{$\begin{array}{c}\text { Panjang/Tinggi } \\
\text { Badan menurut } \\
\text { Umur }(\mathrm{PB} / \mathrm{U})\end{array}$} & Sangat Pendek & $<-3 \mathrm{SD}$ \\
\hline & Pendek & $3 \mathrm{SD}$ to $<-2 \mathrm{SD}$ \\
\hline & Normal & $-2 \mathrm{SD}$ to $2 \mathrm{SD}$ \\
\hline & Tinggi & $>2 \mathrm{SD}$ \\
\hline \multirow{4}{*}{$\begin{array}{c}\text { Berat Badan } \\
\text { menurut } \\
\text { Panjang/Tinggi } \\
\text { Badan (BB/PB) }\end{array}$} & Sangat Kurus & $<-3 \mathrm{SD}$ \\
\hline & Kurus & $3 \mathrm{SD}$ to $<-2 \mathrm{SD}$ \\
\hline & Normal & $-2 \mathrm{SD}$ to $2 \mathrm{SD}$ \\
\hline & Gemuk & $>2 \mathrm{SD}$ \\
\hline \multirow{4}{*}{$\begin{array}{c}\text { Indeks Massa } \\
\text { Tubuh menurut } \\
\text { Umur }\end{array}$} & Sangat Kurus & $<-3 \mathrm{SD}$ \\
\hline & Kurus & $3 \mathrm{SD}$ to $<-2 \mathrm{SD}$ \\
\hline & Normal & $-2 \mathrm{SD}$ to $2 \mathrm{SD}$ \\
\hline & Gemuk & $>2 \mathrm{SD}$ \\
\hline
\end{tabular}

Cara menentukan ambang batas untuk mengukur kategori status gizi anak adalah dengan melakukan pengukuran berat badan anak. Setelah mengetahui berat badan dan umur anak, kemudian mencocokkan dengan ambang batas yang sesuai dengan berat badan dan umur anak. Setelah mendapatkan ambang batas anak, selanjutnya adalah mencocokkan kategoori status gizi anak pada tabel kategori dan ambang batas status gizi anak berdasarkan indeks. Dalam melihat tabel tersebut, indeks yang digunakan untuk mengukur kategori status gizi harus sesuai. Untuk contoh yang digunakan pada kasus ini adalah menggunakan indeks berat badan menurut umur. Setelah itu, kategori status gizi disesuaikan berdasarkan ambang batas dan indeks yang digunakan.

\section{HASIL DAN PEMBAHASAN}

Untuk melakukan implementasi sistem, diperlukan proses desan dan analisis yang baik. Dalam penelitian ini, dilakukan analisis melalui proses wawancara dan pemantauan langsung di Kelurahan X.
A. Analisis Kondisi Saat Ini dan Masalah yang Dihadapi

Proses analisis kondisi saat ini dilakukan selama satu minggu terhadap beberapa Posyandu di Keluarahan Banjar Tengah, Kecamatan Negara, Kabupaten Jembrana, Bali [8]. Proses wawancara dilakukan pada bidan dan kader yang bertanggung jawab pada Posyandu-Posyandu di Kelurahan Banjar Tengah. Sedangkan wawancara pada orang tua dilakukan kepada lima orang tua yang memiliki anak yang tercatat di Posyandu Kesari dan lima orang tua yang memiliki anak yang tercatat di Posyandu Kamboja 741 yang ada di Kelurahan Banjar Tengah, Bali.

Saat ini, data tumbuh kembang anak dilakukan dengan mengandalkan Kartu Menuju Sehat (KMS), seperti pada Gambar 1. KMS ini dipegang sendiri oleh orang tua anak. Jika KMS tertinggal atau hilang, maka petugas Posyandu / kader akan membuatkan kartu sementara untuk mencatat data anak saat penimbangan. Selain pada KMS, petugas Posyandu juga mencatat data tumbuh kembang anak pada buku Register Kohort, dimana buku Register Kohort terbagi menjadi dua bagian, yaitu untuk bayi 0-11bulan, dan anak 15tahun. Dalam buku Register Kohort ini, dicatat data anak meliputi nama, tanggal lahir, jenis kelamin, informasi orang tua, histori tinggi, berat badan dan lingkar kepala, tanggal pemberian imunisasi serta tanggal pemberian vitamin A. Buku Register Kohort ini digunakan sebagai dasar penilaian status gizi anak, yang diterbitkan setiap bulan untuk diserahkan pada Kelurahan dan Puskesmas terkait. Proses ini akan menimbulkan masalah, ketika pada hari $\mathrm{H}$ jadwal pengukuran anak, anak berada di lokasi Posyandu yang bukan asalnya dan tidak membawa KMS. Petugas Posyandu harus memeriksa Buku Register Kohort secara cermat untuk mengetahui kondisi tumbuh kembang anak tersebut. Selain itu, seringkali petugas menghitung status gizi anak secara perkiraan, karena keterbatasan waktu pelaksanaan di lapangan, sehingga hal ini dapat memungkinkan adanya tingkat error yang cukup tinggi pada proses pelaporan ke Puskesmas.

Secara rutin, Posyandu juga mengadakan kegiatan sesuai dengan instruksi dari Puskesmas. Kegiatan ini diinformasikan secara mulut ke mulut dari petugas Posyandu ke kader, dan kemudian dilanjutkan ke anggota Posyandu.Seringkali orang tua anak mengetahui kegiatan ini ketika hari pelaksanaannya. Hal ini berdampak pada tingkat keberhasilan kegiatan. Contoh pelaksanaan imunisasi MR yang dilakukan serentak oleh Pemerintah, Posyandu pada daerah ini mengandalkan penyebaran informasi antar anggotanya saja, sehingga terdapat kemungkinan ada anggota yang tidak mendapatkan informasi atau terlambat mengetahuinya, sehingga tidak mendapatkan imunisasi MR yang seharusnya bersifat wajib.

Dalam sistem keuangan, tidak banyak kegiatan yang terjadi dalam Posyandu, karena bahan baku makanan, vaksin dan vitamin yang didistribusikan untuk anggota Posyandu, telah disediakan oleh Puskesmas. Dana kas yang dimiliki oleh Posyandu merupakan swadaya anggota, dan digunakan untuk pembelian alat tulis serta alat penunjang lainnya. Dana keluar masuknya kas, dicatat dalam bentuk dokumen insidentil. 
Setiap akhir periode kegiatan (pada umumnya satu bulan), petugas medis yang bertanggung jawab terhadap seluruh Posyandu yang berada dalam satu kelurahan, wajib menyusun beberapa laporan, meliputi laporan bulanan gizi baru, laporan status gizi balita berdasarkan kelompok umur, laporan imunisasi rutin, dan laporan PWS (Pemantauan Wilayah Setempat) imunisasi dasar, booster DTP HIB, campak dan TT5. Laporan bulanan gizi baru merupakan laporan hasil akumulasi jumlah balita di masing-masing Posyandu di satu kelurahan sesuai indikator yang ada.

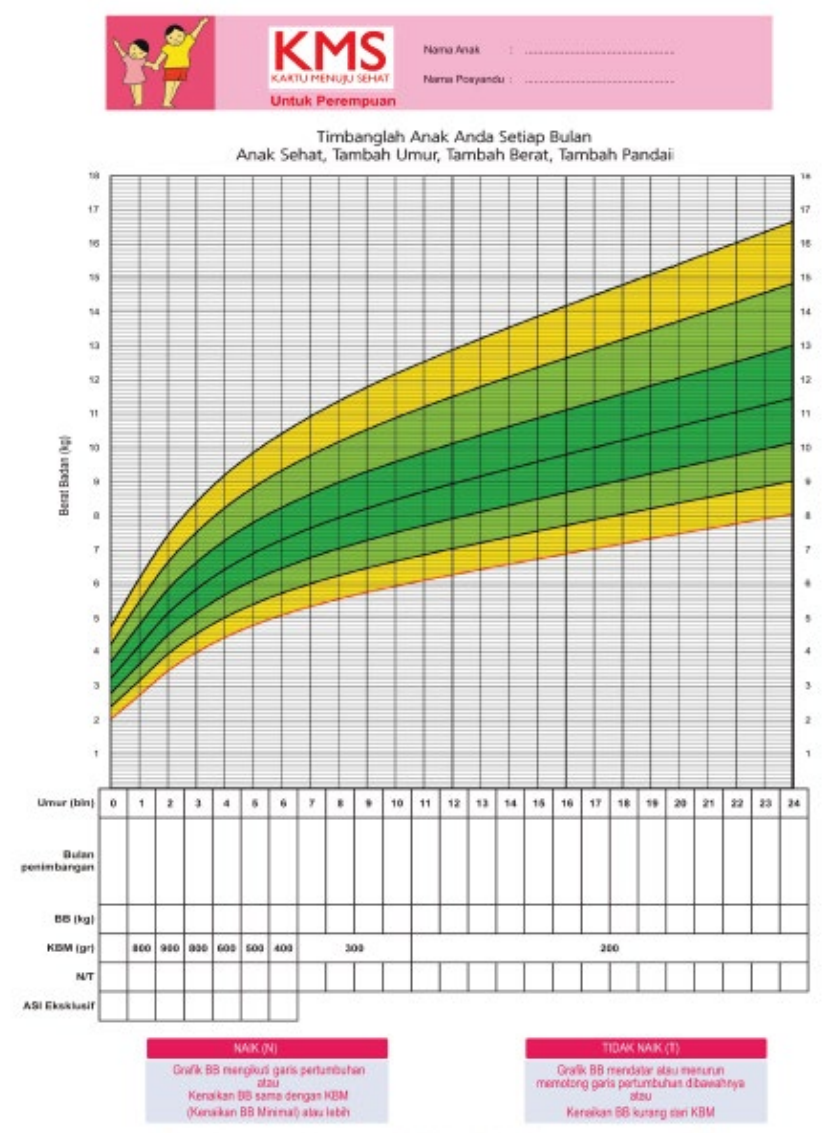

Gambar 1. KMS

Laporan status gizi balita berdasarkan kelompok umur merupakan laporan yang berisi akumulasi jumlah balita yang memiliki gizi lebih, gizi baik, gizi kurang, maupun gizi buruk berdasarkan usia dan Posyandu balita. Laporan imunisasi rutin merupakan laporan yang berisi akumulasi jumlah balita yang menerima imunisasi berdasarkan jenis kelamin dan Posyandu balita. Laporan PWS, imunisasi dasar, booster DPT-HIB, campak dan TT5 merupakan laporan akumulasi dalam persen mengenai jumlah balita yang menerima imunisasi berdasarkan lingkungan Posyandu. Kompleksitas laporan yang harus dibuat setiap bulannya, membuat petugas medis terbeban dengan tugas yang cukup banyak pada setiap akhir periode. Hal ini memunculkan kemungkinan keterlambatan penerbitan laporan serta data yang tidak akurat karena human error.
Secara keseluruhan, proses yang terjadi pada Posyandu digambarkan dalam Business Process Model and Notation (BPMN), seperti pada Gambar 2.

\section{B. Kebutuhan Sistem}

Berdasarkan analisis yang telah dilakukan, maka dapat diambil kesimpulan bahwa untuk membantu proses yang terjadi dalam Posyandu, dibutuhkan suatu sistem terintegrasi yang dapat diakses oleh petugas puskesmas, petugas Posyandu, serta anggota Posyandu. Sistem ini akan direalisasikan dalam bentuk aplikasi website dan mobile. Aplikasi website dapat digunakan oleh semua user yang terdaftar, terutama petugas puskesmas dan Posyandu, untuk membantu entri data pada sistem. Sedangkan aplikasi mobile, dapat digunakan oleh anggota Posyandu, untuk membantu pendistribusian informasi kegiatan, pencatatan kegiatan anak, serta pengingat jadwal yang dibutuhkan.

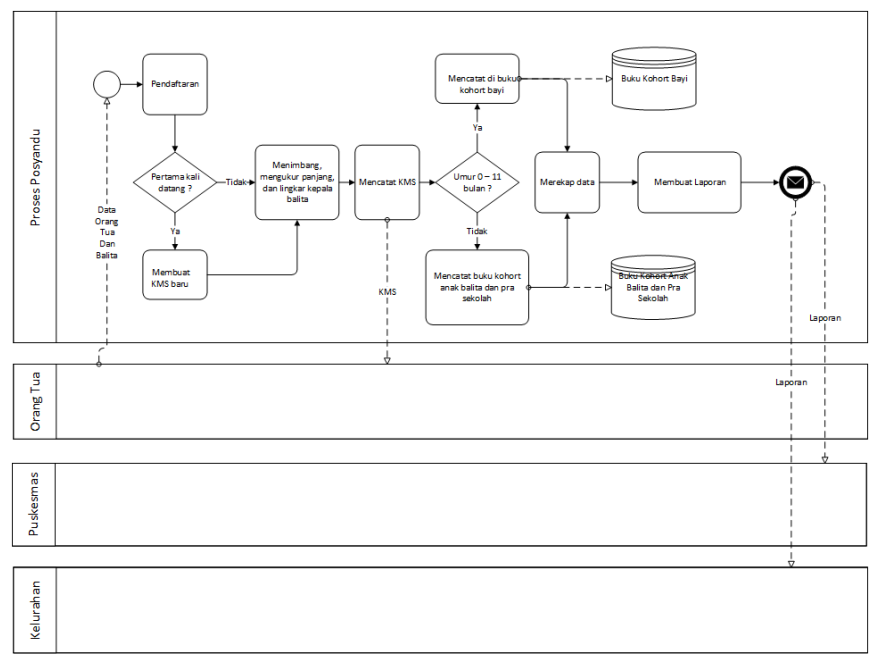

Gambar 2. BPMN Sistem Saat Ini

C. Desain Proses dan Data

Representasi prosesdigambarkan dalam bentuk BPMN [9], sedangkan representasi data digambarkan dalam bentuk Entity Relationship Diagram (ERD). Desain basis data untuk sistem Posyandu dapat dilihat pada Gambar 3. Sedangkan untuk desain proses, dibagi menjadi beberapa bagian utama, dan dijelaskan pada bagian berikutnya.

\section{C.1. Pendaftaran Anak}

Seiring dengan membaiknya infrastruktur yang dimiliki oleh Pemerintah terkait dengan data kependudukan, maka Puskesmas dan Posyandu dapat secara aktif melakukan pendataan pada anggotanya. Secara berkala, data kependudukan difilter berdasarkan alamat tinggalnya, dan petugas Posyandu akan mendapatkan informasi bayi/anak baru yang masuk ke areanya. 


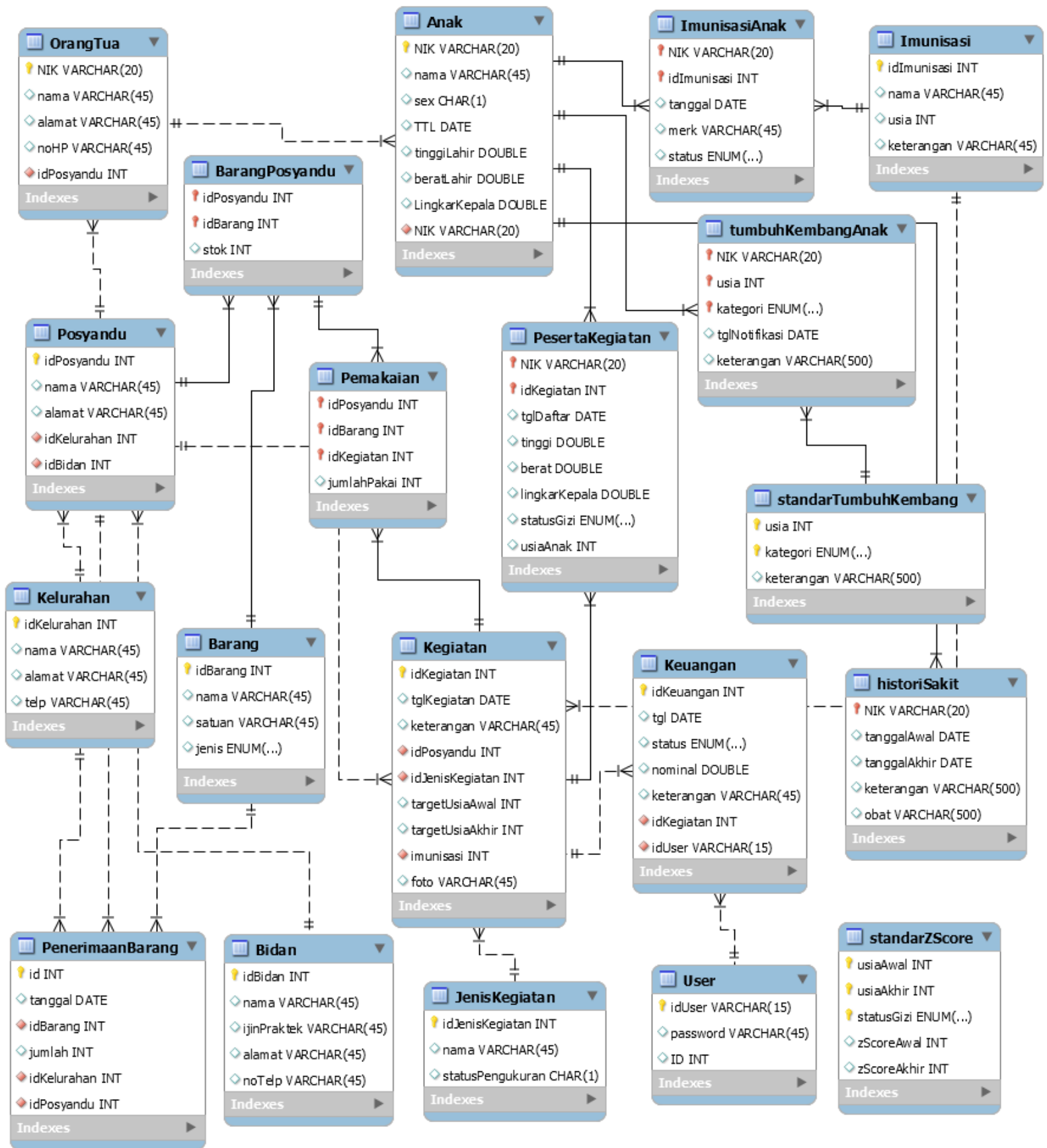

Gambar 3. Desain Basis Data 
Setelah mendapatkan data bayi/anak baru, maka petugas secara aktif melakukan konfirmasi ke nomor telepon yang terdaftar. Apabila orang tua setuju dengan keanggotaannya di Posyandu tersebut, maka ia wajib mengunduh aplikasi mobile Posyandu dan melakukan registrasi dengan NIK yang dimilikinya. BPMN untuk proses pendaftaran anak dapat dilihat pada Gambar 4.

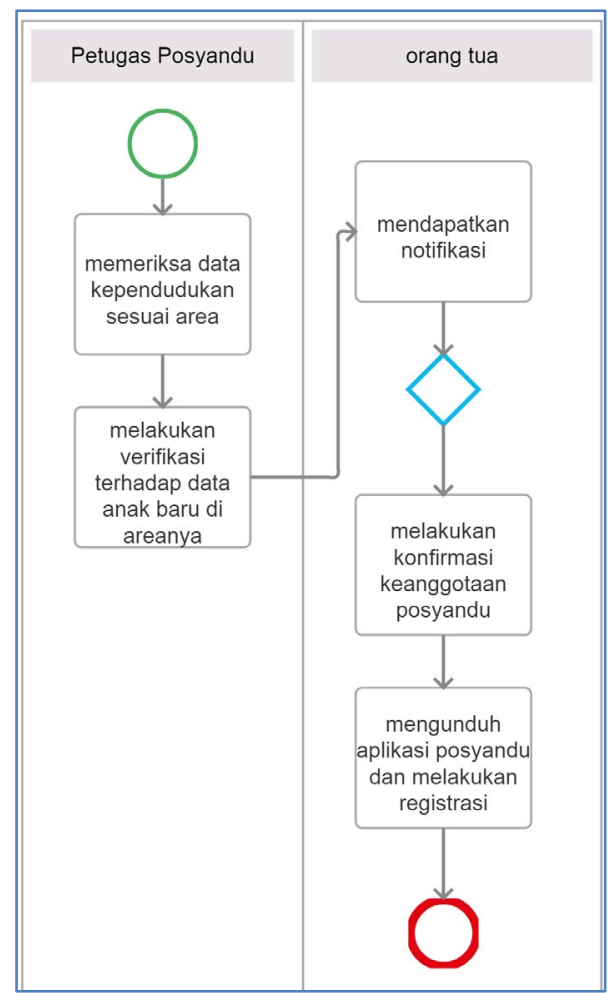

Gambar 4. BPMN untuk proses pendaftaran

\section{C.2. Kegiatan Posyandu}

Petugas dapat melakukan input kegiatan yang akan dilaksanakan melalui website Posyandu terpadu. Informasi yang dicatat meliputi:

- Tanggal pelaksanaan

- Detail kegiatan: pengukuran, pemeriksaan anak/ibu hamil, imunisasi, penyuluhan, pelatihan.

- Keterangan kegiatan

- Usia bayi yang menjadi target dalam kegiatan

- Imunisasi yang disediakan (jika ada)

Apabila kegiatan sudah diinputkan, petugas dapat melakukan pengiriman notifikasi ke semua anggota Posyandu yang masuk dalam target kegiatan. Ketika orang tua yang menjadi anggota kegiatan menerima notifikasi dari Posyandu, mereka dapat melakukan konfirmasi akan mengikuti kegiatan tersebut atau tidak. Selain itu, anggota lain yang tidak memiliki anak di usia yang menjadi target kegiatan juga dapat mendaftarkan diri untuk mengikuti kegiatan ini, dengan mendaftarkan diri secara manual melalui aplikasi mobile yang ada di handphonenya, atau melalui website Posyandu. BPMN untuk proses kegiatan dapat dilihat pada Gambar 5.

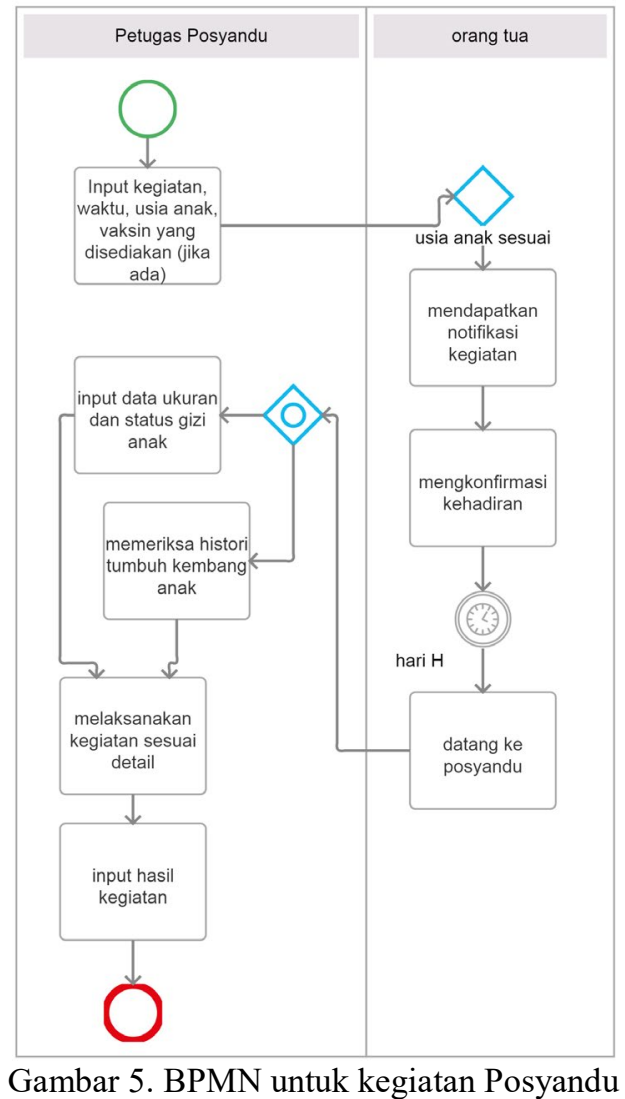

Pada hari pelaksanaan kegiatan, petugas Posyandu telah memiliki daftar peserta kegiatan, sesuai dengan anggota yang mendaftarkan diri. Petugas akan melakukan pengukuran pada setiap anak, termasuk berat, tinggi, lingkar kepala, dan melakukan wawancara singkat pada orang tua untuk mengetahui pola asuh anak dan menentukan status gizi anak. Sistem secara otomatis dapat memberikan status gizi sesuai ukuran yang diinputkan, dibandingkan dengan usia anak dan standar ukuran anak yang telah ditetapkan oleh WHO (Tabel 1). Selain itu, petugas dapat memeriksa histori tumbuh kembang anak, dengan melihat catatan di database, sesuai dengan keterangan yang diinputkan oleh orang tua.

Apabila pada kegiatan tersebut ada pemberian imunisasi, maka petugas akan memberikan imunisasi pada bayi/anak yang telah terdaftar. Pemberian imunisasi hanya diberikan pada bayi/anak yang menjadi anggota di Posyandu tersebut. Sedangkan untuk anggota Posyandu lain, dapat mengikuti semua kegiatan selain imunisasi. Setelah itu, petugas akan melaksanakan kegiatan sesuai yang direncanakan, seperti pemberian makanan sehat, penyuluhan $\mathrm{KB}$, pelatihan untuk $\mathrm{ibu}$, dan lain sebagainya. Desain tampilan untuk kegiatan ini dapat dilihat pada Gambar 6 .

Setelah acara selesai, petugas akan menginputkan hasil kegiatan, pemakaian dana dan barang, petugas yang bertanggung jawab serta mengunggah foto kegiatan untuk dipasang di situs Posyandu. Pada akhir periode, sistem dapat menampilkan laporan kondisi gizi anak, seperti desain tampilan pada Gambar 7. 


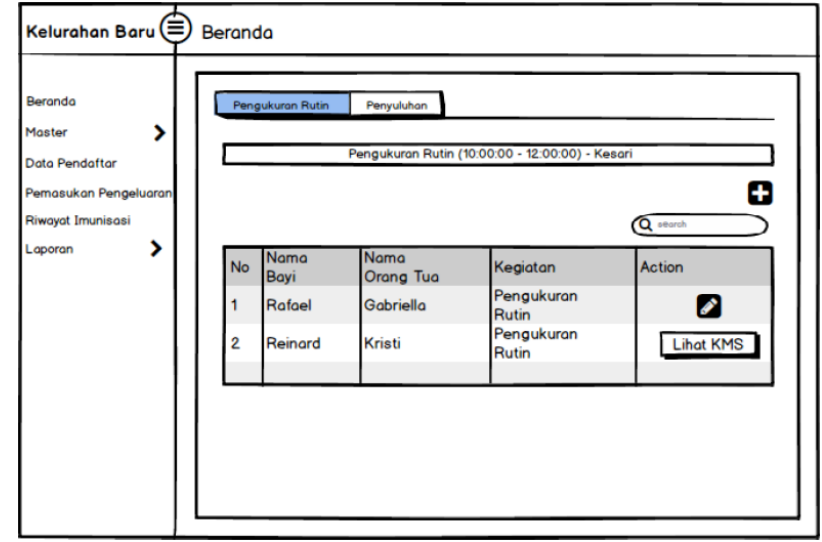

Gambar 6. Desain Interface Kegiatan Posyandu

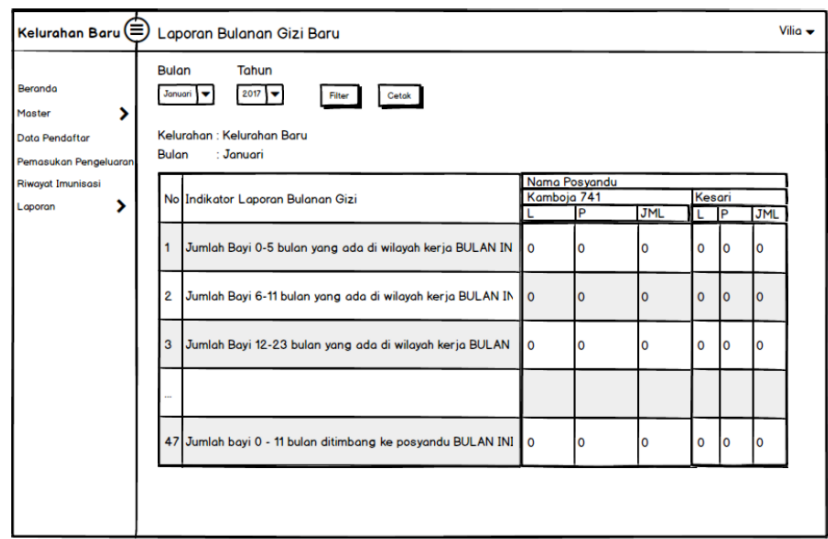

Gambar 7. Desain Interface Laporan Kondisi Gizi Anak

Data tumbuh kembang anak dapat diakses oleh Kader/Petugas Posyandu maupun orang tua melalui situs Posyandu. KMS anak ditampilkan dalam bentuk grafik, sehingga Kader, petugas Posyandu maupun orang tua anak dapat melihat dengan mudah kondisi anaknya. Implementasi KMS dapat dilihat pada Gambar 8.

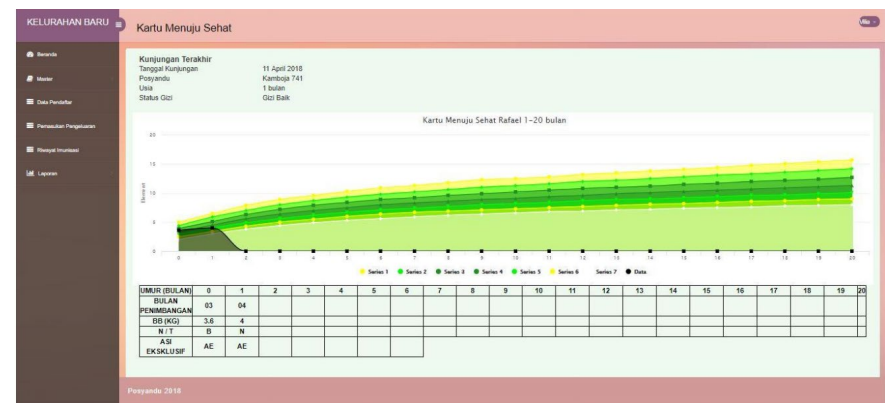

Gambar 8. Implementasi KMS

Petugas Posyandu dapat mencatat pengeluaran real yang terkait pada kegiatan tertentu, untuk dilaporkan ke Kelurahan, seperti data penggunaan vaksin, PMT dan lain sebagainya. Implementasi pencatatn pengeluaran kegiatan dapat dilihat pada Gambar 9.

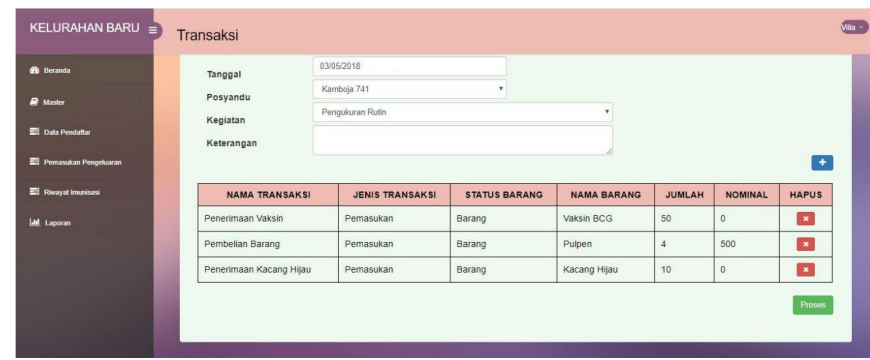

Gambar 9. Implementasi Pencatatan Pengeluaran

\section{C.3. Pengingat}

Aplikasi mobile yang dimiliki oleh anggota Posyandu memiliki fitur pengingat untuk jadwal imunisasi dan tumbuh kembang anak, sesuai dengan usia anak. Desain tampilkan dapat dilihat pada Gambar 10. Pada pengingat jadwal imunisasi, orang tua dapat memberikan tanda jika imunisasi sudah dilakukan sendiri (tidak melalui Posyandu), dengan menginputkan tanggal pelaksanaan dan merk imunisasi yang diberikan. Orang tua juga dapat memberikan tanda apabila ia tidak berniat memberikan imunisasi tersebut pada anaknya. Desain tampilan dapat dilihat pada Gambar 11.

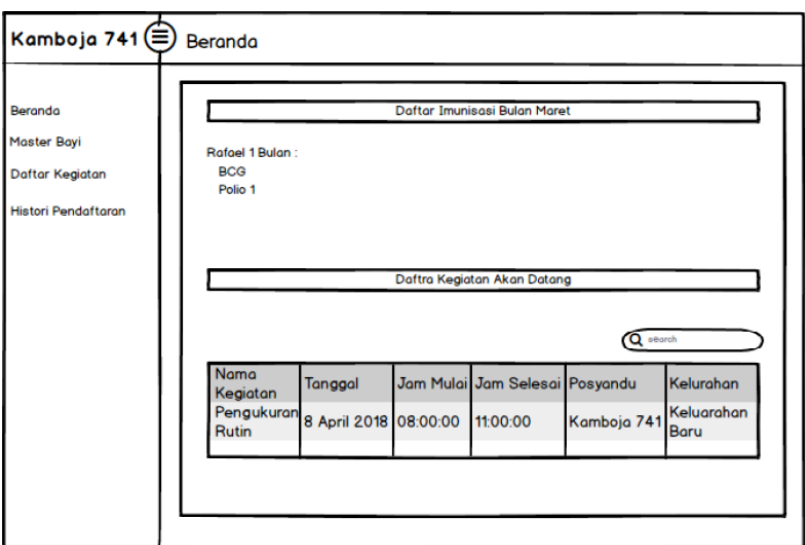

Gambar 10. Desain Interface Pengingat Imunisasi dan Kegiatan untuk Orang Tua

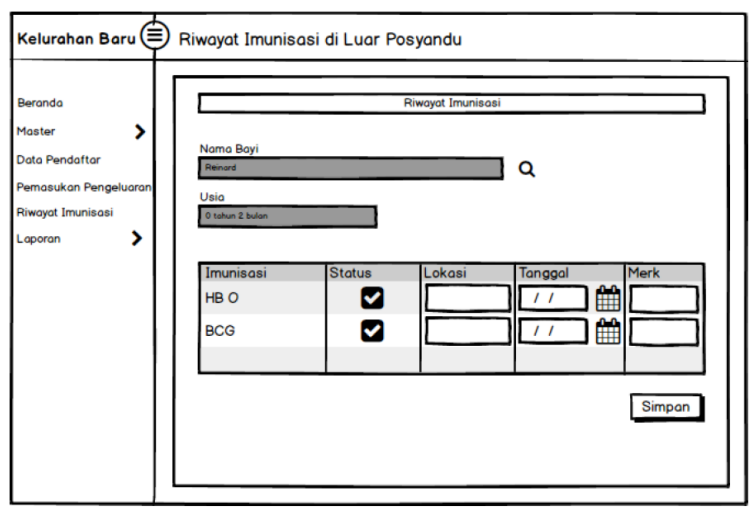

Gambar 11. Desain Interface Riwayat Imunisasi Anak

Pada pengingat tumbuh kembang anak, orang tua akan mendapatkan informasi milestone yang sewajarnya dicapai anak pada usianya. Contoh informasi milestone ini antara lain: 
- Pada usia 4 bulan, dalam pertumbuhan motorik anak, seharusnya anak dapat menegakkan kepalanya dengan stabil

- Pada usia 11 bulan, dalam pertumbuhan bahasa anak, seharusnya anak dapat memanggil ayah/ibu

- Pada usia 24 bulan, dalam pertumbuhan motorik halus, seharusnya anak dapat memegang pensil dan menarik garis lurus.

Secara berkala, orang tua akan menerima notifikasi tumbuh kembang ini pada telepon selulernya. Orang tua dapat memberikan konfirmasi kondisi anaknya, sudah tercapai atau belum, serta memberikan catatan terkait dengan tumbuh kembang tersebut.

Selain itu, sistem juga dapat memberikan pengingat terkait kegiatan yang diadakan oleh Posyandu. Pada saat sistem mendapatkan inputan kegiatan yang dilengkapi dengan target usia anak, maka sistem secara otomatis akan mengirimkan notifikasi kepada orang tua yang memiliki anak dalam target usia yang ditetapkan.

Dengan adanya fitur pengingat, diharapkan orang tua dapat memiliki perhatian lebih terhadap kegiatan anak di Posyandu dan dapat lebih memperhatikan jadwal vaksin anak yang memiliki pengaruh cukup besar dalam menjaga kesehatan anak. Selain itu, dengan adanya informasi milestone tumbuh kembang anak, diharapkan anak-anak dapat tumbuh sesuai usianya dan menjadi pribadi yang sehat.

\section{KESIMPULAN DAN SARAN}

Diharapkan dengan adanya sistem ini, maka petugas Posyandu dapat mengolah informasi dengan lebih baik, sehingga dapat melaksanakan program kegiatan Posyandu yang lebih tepat sasaran, yaitu terkait dengan usia anak dan kebutuhan anak dalam menyokong tumbuh kembangnya.

Selain itu, diharapkan aplikasi ini juga dapat membantu orang tua, agar mendapatkan informasi yang tepat terkait tumbuh kembang anaknya, terkait dengan jadwal imunisasi, milestone pertumbuhan anak, serta kegiatan Posyandu yang sesuai dengan usia anak.

\section{REFERENSI}

[1] Kompas. (2008). 80 Persen Otak Anak Berkembang di Usia Emas. Diakses dari: https://nasional.kompas. com/read/2008/12/20/10101819/80.persen.otak.anak.ber kembang.di.usia.emas pada tanggal 6 Juli 2018

[2] BPS. (2017). Keadaan Angkatan Kerja di Indonesia Agustus 2017. ISSN.0126-647X. Halaman 39. Diakses dari: https://www.bps.go.id/publication/download.html pada tanggal 6 Juli 2018.

[3] Kementrian Kesehatan RI. (2012). Ayo Ke Posyandu Setiap Bulan. Diakses dari: http://www.depkes.go.id/ resources/download/promosi-kesehatan/buku-sakuPosyandu.pdf pada tanggal 6 Juli 2018.
[4] Saepudin E., Rizal E., Rusman, A. (2017). Peran Posyandu Sebagai Pusat Informasi Kesehatan Ibu dan Anak. Record and Library Journal, Vol. 3, No. 2, JuliDesember 2017. e-ISSN 2442-5168. Diakses dari https://e-journal.unair.ac.id/RLJ/article/viewFile/7338/ 4439 pada tanggal 6 Juli 2018.

[5] Kementrian Komunikasi dan Informatika Republik Indonesia. (2015). Indonesia Raksasa Teknologi Digital Asia. Diakses dari https://www.kominfo.go.id/ content/detail/6095/indonesia-raksasa-teknologi-digitalasia/0/sorotan_media pada tanggal 6 Juli 2018.

[6] OkeZone Finance. (2018). Indonesia Pengguna Smartphone Ke-4 Dunia, Begini Tekad Menperin Dongkrak Industri Telematika. Diakses dari: https://economy.okezone.com/read/2018/02/17/320/186 0752/indonesia-pengguna-smartphone-ke-4-duniabegini-tekad-menperin-dongkrak-industri-telematika pada tanggal 6 Juli 2018

[7] Kementrian Kesehatan RI. (2011). Keputusan Menteri Kesehatan Republik Indonesia Nomor: 1995/Menkes/ SK/XII/2010 tentang Standar Antropometri Penilaian Status Gizi Anak. Jakarta: Kementerian Kesehatan RI Direktoral Jenderal Bina Gizi dan Kesehatan Ibu dan Anak.

[8] Kristi, V., Tresna, D., Liliana. (2018). Pembuatan Sistem Informasi Posyandu di Kecamatan "X" Berbasis Web. 160414031 - Tugas Akhir Teknik Informatika, Universitas Surabaya.

[9] BPMN Studio (nd). Free Online Service for Business Process Modeling. Diakses dari: https://bpmn.studio/ main/processes/id/5b4856ffac3c4e000169cfac pada tanggal 13 Juli 2018 